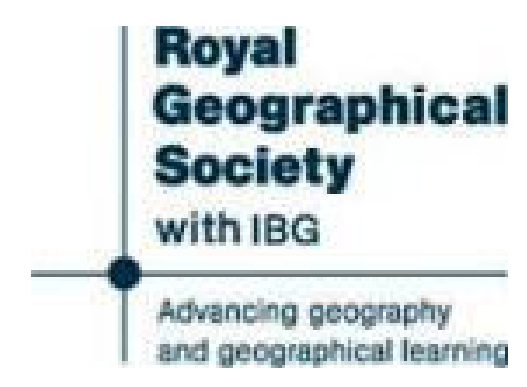

The Spanish Zones in Morocco (Continued) Author(s): H. E. Señor Don Alfonso Merry del Val

Source: The Geographical Journal, Vol. 55, No. 6 (Jun., 1920), pp. 409-419

Published by: The Royal Geographical Society (with the Institute of British Geographers)

Stable URL: http://www.jstor.org/stable/1780966

Accessed: 06/01/2015 00:14

Your use of the JSTOR archive indicates your acceptance of the Terms \& Conditions of Use, available at

http://www.jstor.org/page/info/about/policies/terms.jsp

JSTOR is a not-for-profit service that helps scholars, researchers, and students discover, use, and build upon a wide range of content in a trusted digital archive. We use information technology and tools to increase productivity and facilitate new forms of scholarship. For more information about JSTOR, please contact support@jstor.org. 


\section{The Geographical Journal}

Vol. LV No. 6

June I920

\section{THE SPANISH ZONES IN MOROCCO}

\section{H. E. Señor Don Alfonso Merry del Val, Spanish Ambassador}

\section{(Continued from page 349.)}

\section{$\mathrm{T}$} OWARDS the close of the fifteenth century, the dawn of Spain's power on land and sea, 800 miles of the Atlantic coast opposite the Archipelago had been pláced under the banner of Castile. Of the various strongholds and establishments which studded the region, the most important was Santa Cruz de Mar Pequeña. Here the Canary islanders, hardy navigators and industrious fishermen, had founded a station, which through their bravery and able policy became in time the dominant centre of the whole of the Wad Nun district, the natives of which signed a deed of vassalage to the Crown of Castile, represented by Don Lope Sanchez de Valenzuela, Governor of Grand Canary. This settlement, lost in 1524 , at a time when the plague in the islands cut off all succour, has been identified as the contemporary Side Ifni. Successive treaties with Moorish Sultans have consecrated the right of Spanish possession to this site, definitely confirmed by the Treaties of 1912 with Morocco and France.

Ifni constitutes an isolated territory, 60 miles long by $\mathrm{I} 8$ in depth, between Wad Nun or Assaka on the south and Wad Bu Sedra on the north $\left(28^{\circ} 50^{\prime}\right.$ and $29^{\circ} 35^{\prime}$ lat. N. and $\mathrm{I} 2^{\circ} 15^{\prime}$ and $12^{\circ} 55^{\prime}$ long. W. of Paris). Constituted by low-lying and undulated land traversed by several wadi, its climate and general products are those of the Sus. Under irrigation corn of various kinds, vegetables, grapes, dates, pomegranates, the argan, tamarind, gum, and jujube-tree flourish luxuriantly. It is a great breeding country for horses, cattle, sheep, goats and more especially camels of excellent quality. Minerals, chiefly lead, are present in the ground. The principal wealth will, however, one day arise from its proximity to one of the greatest fishing-banks of the world.

The inhabitants are of a more or less mixed Berber and Arab type. As in the north, they are split up into tribes and fractions, governed by local assemblies, or again by Kaids, who exercise feudal power. Some of these great lords nominally represent the Sultan of Morocco, but are in reality the heads of powerful families in whom is vested an authority which 
was never more than a shadow and has been replaced by their own. The Sultan continues, however, to be considered as the spiritual chief.

Although a certain negroid strain is undeniably among these people, and is more clearly marked towards the south, they are of remarkable intelligence and the keenest traders in Morocco, as is well known all over the empire. In other regions they follow the avocations of water-sellers and grocers, but at home they are not so peaceful, and a stranger, particularly a Christian, would find short shrift among them. Their literary talent and the care with which they hand down from generation to generation both the poetical tradition and certain ancient legends explain how many of these men of the south have been called to the Sultan's Court

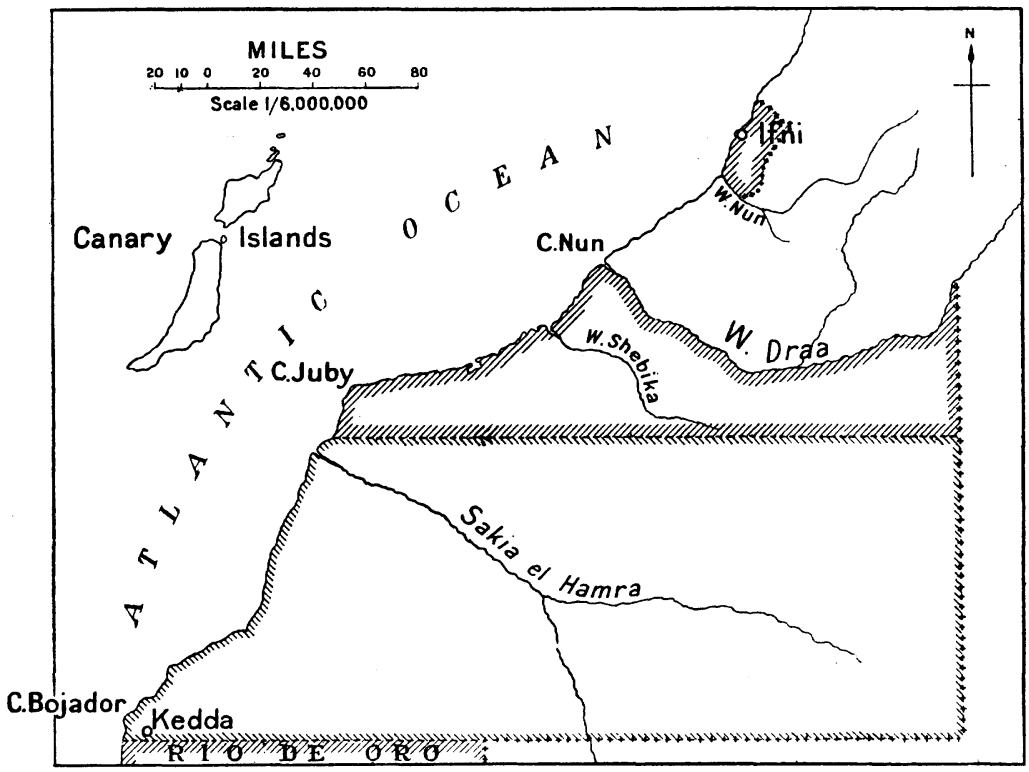

Fig. 3.-Sketch-map showing (I) the Ifni territory; (2).the southern Spanish zone; and (3) the zone which Spain may occupy at pleasure

or by the great Koyad of the Atlas of Abda and Dukkala to give recitals and improvise verses.

The nomads among them use the tents of the Saharan type, but the chiefly pastoral tribes live in dwellings of dried mud or houses built of stone, sometimes two storeys high.

To the south of the Wad Assaka or Nun stretches a strip of the French zone of Protectorate, now completely encircling the Ifni Territory as a consequence of the Treaty of rgr2. Here Spain has again displayed her spirit of extreme conciliation by consenting to reduce this zone of the Protectorate to some 40,000 square miles of territory, just as her forbearance and good will have been shown by postponing time after time the occupation of Ifni, 
From Cape Nun southwards the Spanish zone begins once more, extending on the south to Cape Bojador, the northern limit of our colony of Rio de Oro, and on the east to meridian $\mathrm{II}^{\circ} \mathrm{W}$. of Paris. The famous Sakiet el Hamra marks the extreme limit of the Shereefian Empire, if indeed this realm ever extended so far. There begins a No-man's-land, to which Spain has a recognized right of immediate occupation. In her Zone of Protectorate she has established a post and fishing-station near Cape Juby.

Here the country physiologically belongs to the Sahara, of which it is the natural prolongation. Water is scarce, for the wadis formed by the melting snows of the last spurs of the Anti-Atlas not only run dry in summer, but are at all times sucked up by the sandy soil through which they flow, so that instead of increasing they diminish in their course. Irrigation is nevertheless possible, and the country, by no means sterile, would certainly repay the labour. Vegetation already promises well with but little attention, and the local flocks and herds show how the pastoral resources of the so-called desert land might be developed. The inhabitants appear to belong to the Arab rather than to the Berber type, although the negro admixture is stronger on the Wad Nun. Their intellectual level is lower than further north. Years, however, must pass before this region, so far removed from civilization, can be properly studied under all its aspects, and satisfactorily developed.

I turn now to Spain's work in Morocco. We have seen for ourselves the conditions of the problem of Northern Morocco. A mountainous zone of ro,800 square miles in area, inhabited by over a million natives, of whom 175,000 and 200,000 are tough fighters inured to hardships and armed as well as European infantry. This is a hard nut to crack, particularly as the shell may perhaps have flat edges but no fissure into which to insert a wedge. Spain has attacked this knotty problem, however, and is in the act of solving it. In r909, at a signal from Madrid, the bonds of steel which had enclosed Melilla were triumphantly burst by General Marina, and in less than ten years' time the whole of the territory comprised between the Muluya and the Kert has been occupied. The success of the first military action was so impressive that subsequent operations have been carried out with but little bloodshed. On the west Laraiche and El Ksar were occupied in I9II, and a few months later Tetuan. Here the Gharbia, Khlot, and Tilig districts, of which we have already spoken, were occupied without any great difficulty, as likewise the Hauz of Tetuan, but, exactly as on the east, once the troops came to the hill region the pace necessarily slowed down.

An incident which retarded on this front the general progress of the Spanish occupation was the attitude of El Raisuli. Perhaps the moment has come for a few words concerning this personage. Let me tell you at once that El Raisuli is neither a brigand nor a great military chief ; he is simply a politician-a politician a la mauresque, it is true. Si Ahmed 
ben Mohammed el Raisuli was born a citizen of Tetuan, but his family originated in the holy tribe of Beni-Aros in the heart of Jebala, and being himself, moreover, a descendant of the Prophet through a Marabut whose shrine is venerated in that district, he is a Shereef and therefore much to be revered by all good Mohammedans. Endowed with great ambition, Ahmed el Raisuli conceived the plan of acting as the visible head and spokesman of the confederation of Jebala tribes, always ready when not absorbed in family quarrels to flout and thwart the Sultan's Government, united as they are by a certain sub-consciousness of race and a common veneration for the great Marabut, Muley Abd-es-Salam, he who is buried on the very crest of Jebel Alam and was the progenitor of the Beni Arosi, one and all Shorfa of Islam. El Raisuli's first endeavour was to catch the public eye, to make himself necessary and obnoxious to the Sultan, the better to formulate his demands. Backed up by the Jebala, who gave him the armed force and the strongholds he required, he began by kidnapping a United States citizen and a British subject of note, holding them up to ransom in the fastnesses of the mountains, where the Sultan could not and the Foreign Powers did not trouble to reach him. As a first success he obtained the appointment of Kaid of Tangier, but his behaviour and that of his wild Jebala was so outrageous that he had to be removed. Called up to Fez by the Sultan, on to whose shoulders Great Britain shifted the claim for Kaid Maclean's ransom, El Raisuli only disgorged in return for the post of Governor of Arzila, whence he ruled and looted to the great satisfaction of his countrymen and their common profit. At Arzila it was that the Spanish authorities found him and decided to make him useful in their policy of peaceful penetration.

As long as El Raisuli could reasonably imagine that it was possible for him to maintain his own sweet sway in the style most approved of by the Kaid of the old school, he was submissive and apparently pliant. $\mathrm{He}$ took his pay from Spain and arms and ammunition galore; he consented to have some of his freelances schooled by Spanish instructors; he even pretended to ast as an advance-guard. But soon he became a nuisance, his passive resistance grew to intolerable proportions, his alleged negotiations with the tribesmen proved intrigues in his own interest, and he ended by restiveness and impertinence. With this he sealed his doom. In February, March and April of rgrg the Andjera tribesmen, who had much to complain of Raisuli and were never identified with the Jebala proper, submitted to the Sultan's Khalifa at Tetuan. Their territory was successfully occupied, with slight casualties, by troops from Ceuta, cleverly supported by a feint from Laraiche. In April the submission of part of the Beni Hosmar country to the east. of Tetuan was assured, that of the great and important tribe of Beni Said, likewise bordering on the Rif, having already taken place. About the same time the Jebel Hebib men to the south-west of Andjera came in from the Jebala. In May the great M'talsa tribe to the south-east of Melilla, one of the most formidable in the Rif, admitted 


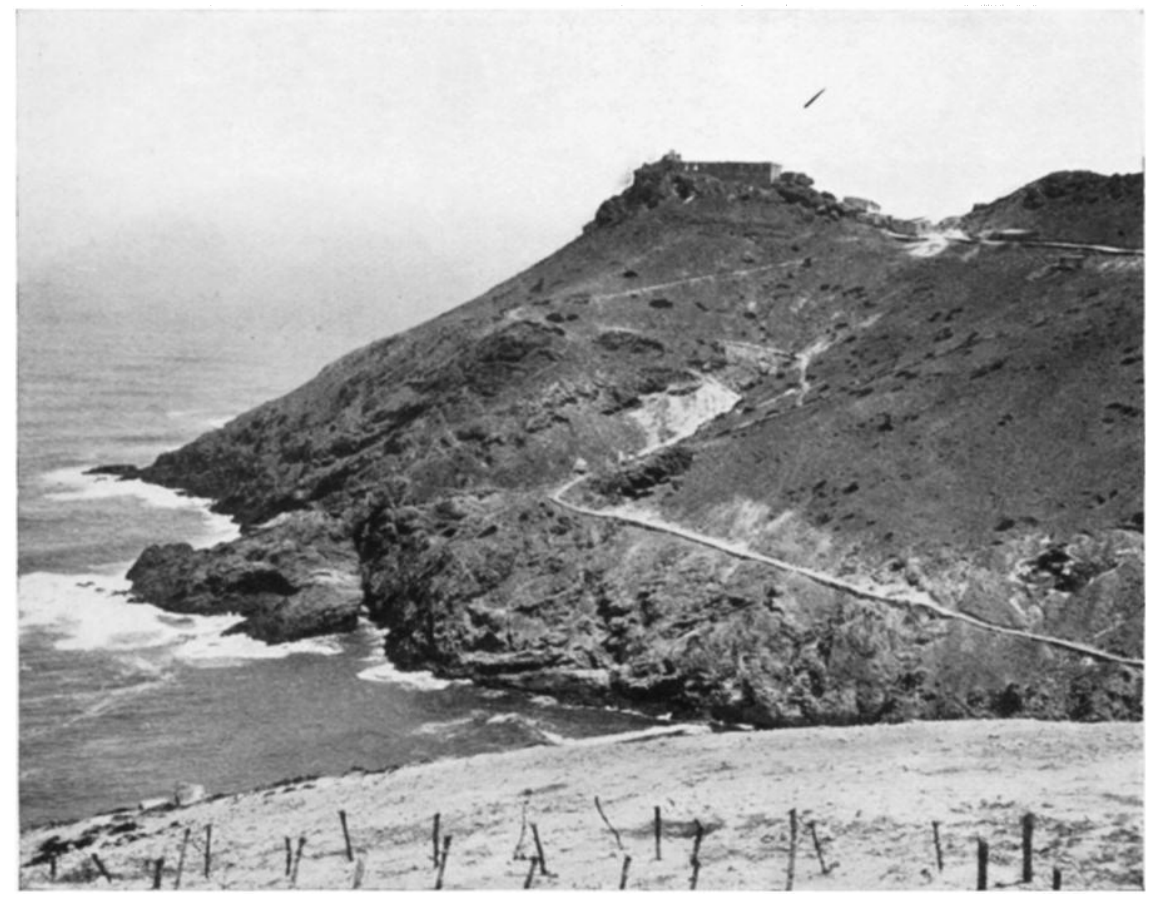

CAPE TRES FORCAS

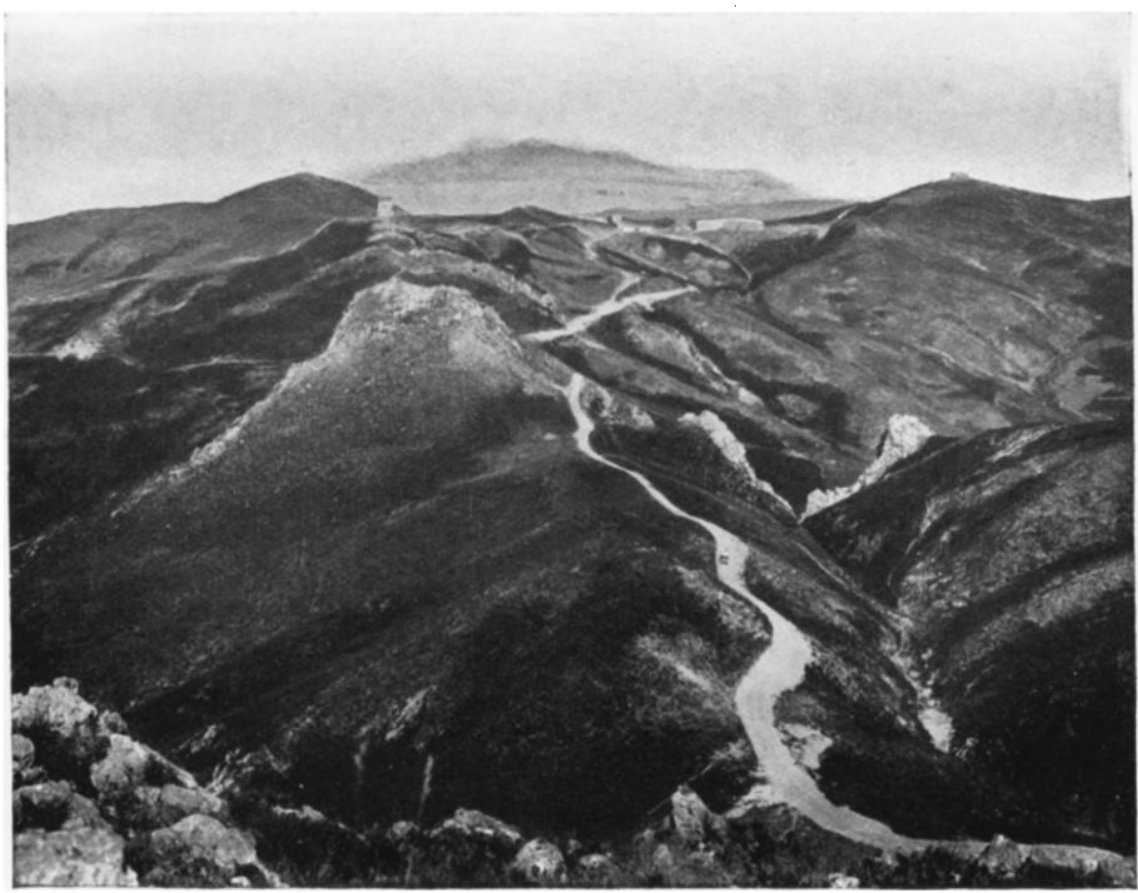

VIEW OVER CEUTA FROM JEBEL INIDER 


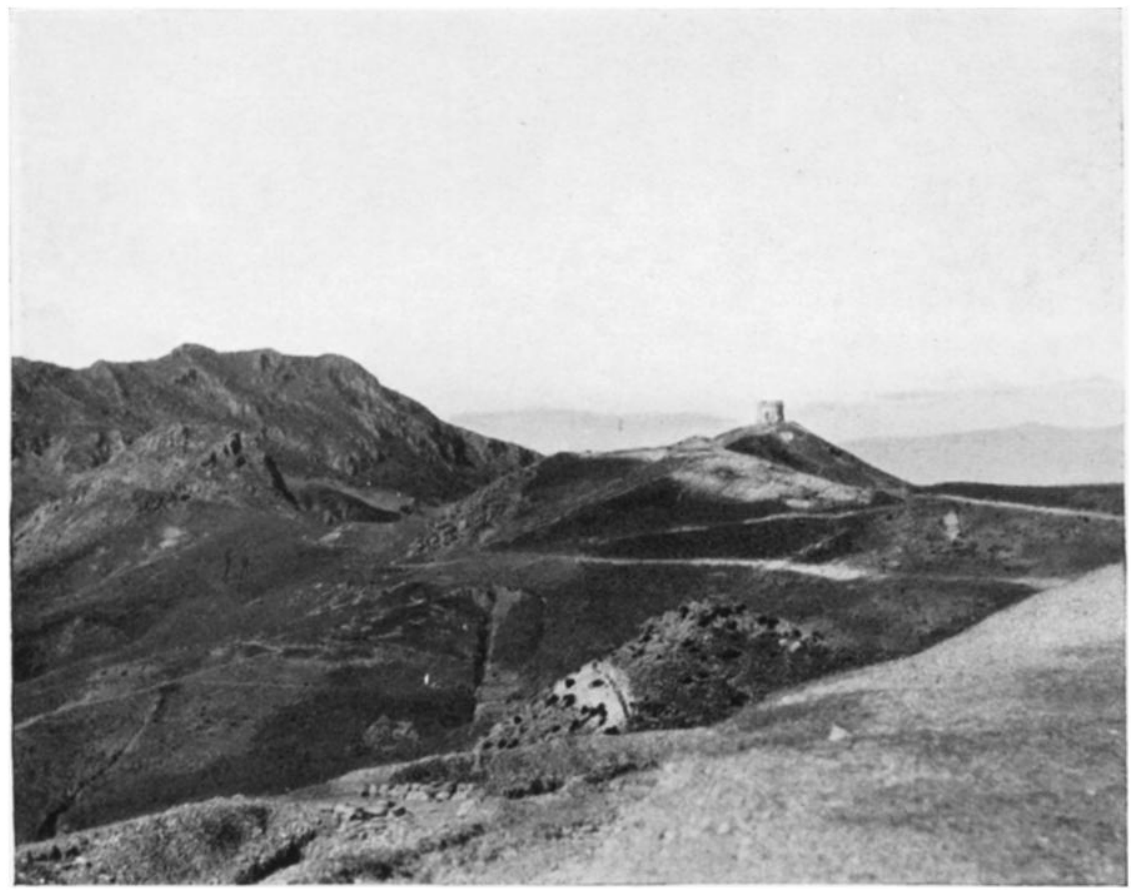

MOUNT SIDI MUSA

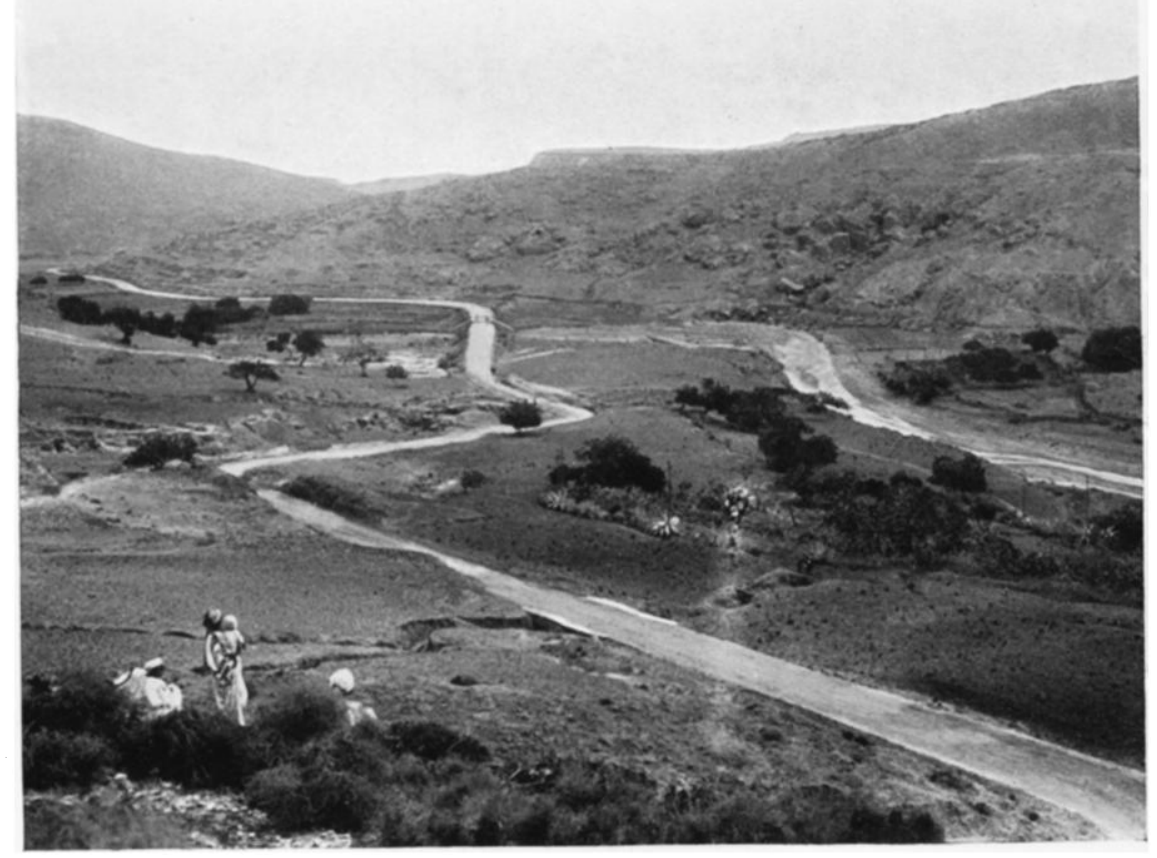

THE ROAD FROM MELILLA TO SAMMAR 
Spanish occupation, and towards the end of the same month the Spanish troops advanced their lines in the Beni bu Yahi country, next to M'talsa, and from Laraiche against the Beni Aros and Beni Gorfet, operating a junction between the Ceuta and Tetuan divisions. On July 1 2-13, Raisuli, realizing that he was being cut off from the coast, attacked but was badly defeated, several key positions on Jebel Zemzem in the Wad Ras country being occupied. Immediately afterwards, at the beginning of August, took place the submission of the Gomara tribe to the Shereefian Khalifa at Tetuan, a fact equivalent in importance to that of the M'talsa a few months previously in the Rif. The close of September (3oth) and first days of October (6th) witnessed the taking of El Fondak of Ain Yedida, Raisuli's principal position, by combined columns operating simultaneously from the Tetuan, Ceuta, and Laraiche districts. Raisuli's power was broken by this defeat, and soon the greater part of the Beni Mesauar and all Wad Ras was occupied, the road from Tetuan to Tangier being definitely cleared. The heavy autumn rains turning the thick clay soil into an impassable slough, it has been necessary to suspend the advance until next spring. Meantime El Raisuli, his fighting force reduced to a handful, has taken refuge at the home of his family at Tasheruts (Beni Aros), within range of the Spanish artillery, unable to pay his men and cut off even from the supplies which used to be sent him from Tangier. $\mathrm{He}$ will no doubt make another attempt before the summer, but his position is very much that of a stag at bay.

If we check the operations above described, we shall see that on the east of the Northern Zone of the Spanish Protectorate the latter has been made effective over all the territory between the rivers Muluya and Kert, and on the west from the sea right up to the Rif on the north and all along the line of the Jebala on the west and south-west. In other words, the two mountain blocks of the Jebala and the Rif are isolated on both sides. Their only communication is with the sea on the north and the French zone of the Protectorate on the south. This is a very satisfactory result which does credit to the Spanish Government and the Spanish Army. We may reasonably hope that it will be carried much further on the road to completion within a relatively short period.

Our aims have been favoured by the influx and establishment of a considerable number of civilian colonists, some 180,000 in all, of whom many are of the same stamp as those hardy countrymen. of ours to whom Algeria owes most of her cultivation and most of her prosperity. The town of Melilla, where in r 909 some 13,000 inhabitants were cooped up within a ring of stone walls and outer forts, has now spread out over the neighbouring plain, once infested at night by marauders from the hills and now covered by broad streets, fine buildings and gardens in which live and work over 77,000 souls. Spanish settlements, some thriving on local trade, some on the neighbouring iron and lead mines, have sprung up almost on the heels of the advancing troops. Their names are Nador, Sok el Arbaa 
de Arkeman, Zeluan, Arruit, Batel, Hasi Berkan, la Restinga, Cabo de Agua. Some of these townships number four and five thousand inhabitants ; many mark the site of fierce engagements between the Moors and the Spanish troops.

Arzila, Ceuta, and Tetuan have under Spanish impulse grown and improved beyond recognition of those who have not seen them since before the war. Ceuta, always and wholly Spanish, numbers some 15,000 within its walls, Tetuan 4000 Spanish inhabitants, as also Laraiche; El Ksar and Arzila somewhat less, excluding the military population. In all these towns European quarters, more or less extensive, are rising from the ground; streets and squares are traced out, levelled and paved, market-places and bridges are built and proper drainage established (see 'Memoria, Public Works,' r9r 7/1918).

At the same time the all-important question of communications has received due attention. A preliminary but comprehensive scheme of roads and railways has been drawn up and already carried out where the state of the country allows of peaceful work. Thus, around Melilla 490 miles of roads have already been finished, leading on the west to the Kert River at Sammar, Izhafen, Tarufen and Tistutin, and on the south to Muley Reshid.

In the Jebala region a road 28 miles long leads from Ceuta to Tetuan, and another 25 miles in length has already reached el Fondak of Ain Yedida, and is actually being continued to Tangier. It will be connected with the network of highways planned for the Andjera territory, of which the most important (Jebel Ider) has been begun. Further south the road from el Ksar to Laraiche has been completed, and now reaches north to beyond Arzila towards Tangier. It is 60 miles in length. Parallel to this and skirting the lower spurs of the Jebala hills, a second road is already planned out and prospected, which in its turn will join the Tetuan-Tangier road with a length of some 50 miles.

This work in itself constitutes an immense step forward in a country where only bridle-paths or at most rough cattle tracks exist. The state of these paths, a mire in winter and a series of holes in summer, can only be understood by those who have seen them and suffered from them. There are no bridges, and communications in the old days were such as to lead Europeans to suspect a deliberate policy on the part of the Maghzen with the purpose of excluding foreigners by increasing the difficulties of transport. The new Spanish roads are well made, and entail a great deal of work in the way of culverts and bridges, necessary to pass the numerous creeks and streams.

Some four railways are already working in the Spanish zone: one, a mining line, runs from Melilla to Mount Afra, 25 miles; another, more important, is a State concern. It reaches down to Zeluan on the south, and to Tistutin on the west, 50 miles, whence it will be continued to Tafersit and eventually to Alhucemas, the finest bay in Morocco and the 
future site of a fine port, while the Melilla-Zeluan line will link up the French zone on the Muluya.

The third line runs from Ceuta to Tetuan along the Hauz coast; it is 27 miles long, and is now actually being continued to Tangier at the same time as the road. A fourth, 8 miles long, connects Tetuan with its port at the mouth of Rio Martin. Between Laraiche and El Ksar a railway is being built which will eventually connect these towns with the projected international line from Tangier to $\mathrm{Fez}$, not yet begun. All these lines are but the beginning of the network of rails which will one day connect Melilla with El Ksar, Laraiche and Tangier by the valleys of the Kert, Warga and Luccus, branching up to Sheshauen and Tetuan, which will in their turn be joined on to the northern line to Badia, Alhucemas, and Melilla.

It is worth noting here that the native soon grasps the value of good means of communication. He works willingly on their construction, and uses them gladly for his own transport and that of his produce. For his trade with foreign lands the ports of Melilla and Ceuta already offer great facilities, but are being further improved, as are the smaller havens of Tetuan, Arzila, and Laraiche, at all of which the Public Works Department of the Spanish Protectorate are actively engaged, have built quays and breakwaters, fitted with appliances for loading and unloading merchandise, are dredging sand-bars, and generally endeavouring to render them useful for commerce, in spite of the great natural difficulties to be overcome. In connection with these works, Spain has built lighthouses, some of them fine works, at Cabo de Agua, Melilla, Cape Tres Forcas, Ceuta and Laraiche, so that the "blind" extensions of coast continually diminish to the great advantage of navigation in those dangerous regions of wind, fog, rocks, and sandbanks.

The mineral wealth of the Northern Zone justifies, in the opinion of the authorities, the existence of a special permanent Commission of Mining Engineers under the Geological Institute of Spain, which is prospecting the occupied districts of the zone, the greater part of which has been properly examined, as will be apparent to those who care to read the Bulletin of the Institute for 1917-18-19 or the yearly reports of the Public Works Department of the Spanish zone.

The iron and lead mines in the northern Spanish zone were the first to be scientifically worked in Morocco, and are already giving excellent results. At San Juan de las Minas in the Beni-bu-Ifrur district Uixan, the efficiently managed Spanish enterprise, "Compañia Española de Minas del Rif," with its own railway service and quay at Melilla, exported in I 918 close on 200,000 tons of mineral, with a percentage of 63.72 per cent. of iron, on forty-seven steamers, all of which unloaded in British ports, as was the case during the whole of the war.

Other companies, such as the Setolazar. Mining Company, shipped that same year to Great Britain and France 60,635 tons, and la Alicantina 5622 to this country, that is a total for 1918 of 287,799 tons of iron ore. 
At the same time the Franco-Spanish Compañia Minera del Norte Africano sent I 790 tons of calamine to France and I99 I tons to Spain.

Another branch of Spanish activity is that of electricity. Electric light was first introduced by Spain into Morocco at Tangier, as was the telephone, as far back as r880. The Tangier electric light works have considerably developed of late years and employ a large staff. All the large towns occupied by Spain in her Northern Zone of the Protectorate are fitted with the same illuminant, and the mining companies furnish it to the neighbouring townships, as at Zeluan, where extensive workmen's quarters and dwellings have been built.

Not only has the telegraph and telephone service stretched its network over the whole of the eastern district of the Spanish Northern Zone, but its lines run over the western region, so that it is possible to converse between Tetuan, Arzila, Laraiche and El Ksar el Kebir by a connection $1 \mathrm{r} 6$ miles in length. The postal service by train and motorcar has been established over all the occupied territory, with its attendant savings-banks and money-orders.

Another boon of civilization introduced by Spain into her Northern Zone of the Protectorate is the proper organization of the water-supply, a signal service in a country so frequently deprived of the precious liquid, and where the springs and wells are so often polluted by the carelessness of the natives. Wherever a military station is established, the first care is to collect, enlarge, and permanently protect the local sources. The supply of the larger towns is properly regulated and assured, and in some, such as Tetuan, these waterworks are quite ornamental. Proper arrangements are made so that the natives may draw the water and their cattle drink it with all facility.

Agriculture has not been neglected in the Northern Sphere of the Spanish Protectorate. The obstacles to its encouragement are many and great; the unfavourable conditions of the soil and climate in some places, in others the land tenure so precarious as to depend upon the mulkia, or affidavit, of witnesses, and often split up into Crown lands, common lands, and property belonging to the Habuz foundations, equivalent to the Egyptian Wakf. Land registration in such conditions becomes difficult and delicate business, prone to originate discontent among the natives. Add to all this the backward state of ideas and of native tillage of the soil. Spain's first step in this all-important branch of human activity was the foundation of a model farm or agricultural school at Melilla, covering I 20 hectares, and provided with stables, barns, cattle-sheds, sheep-folds, and stores for mineral fertilizers. It possesses a laboratory and agricultural machinery of the latest pattern. Two offshoots of this farm exist at Zeluan and El Zaio in the heart of the Eastern Rif and on the Muluya. In the Western Zone there is another State farm on the road from Laraiche to El Ksar, occupying the Shereefian property of the Adir. This is dedicated for the greater part to a stud and sheep farm, but 


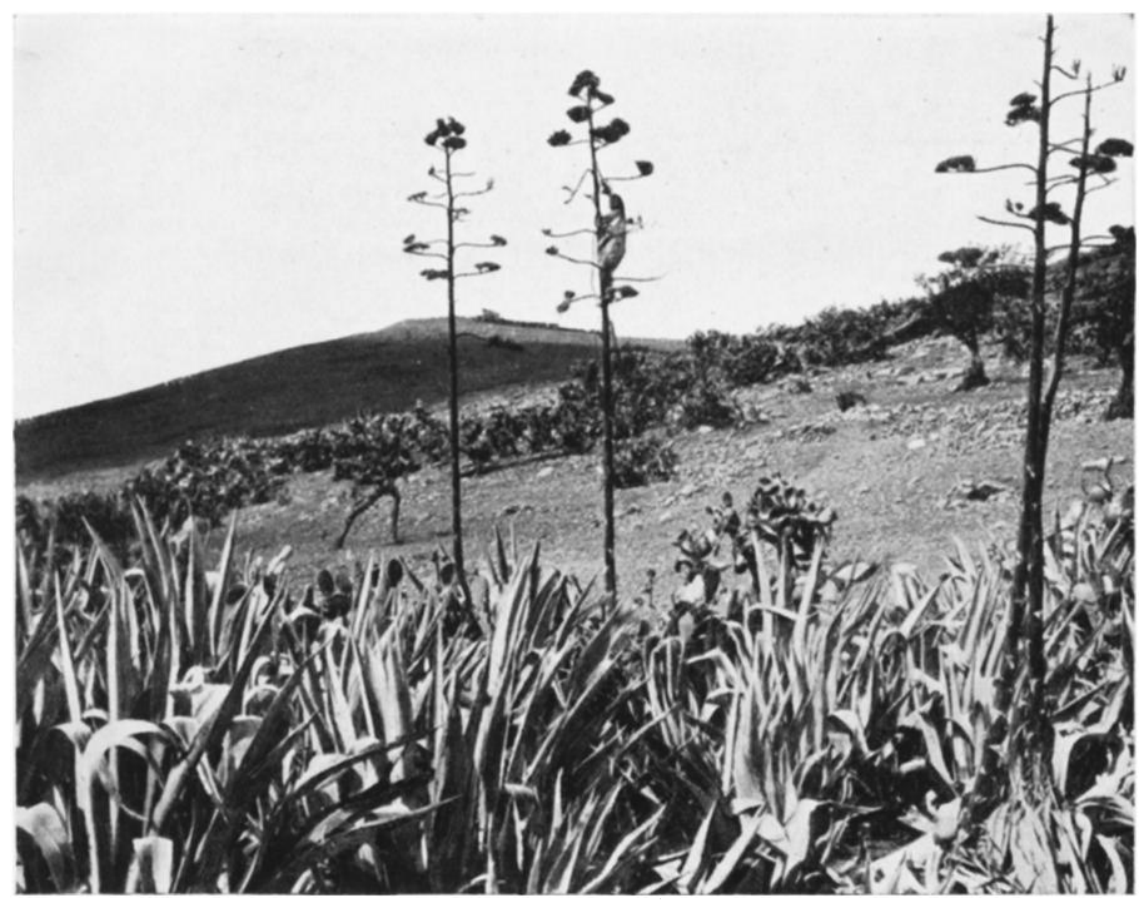

ON MOUNT ARBOS, SOUTH OF MELILLA

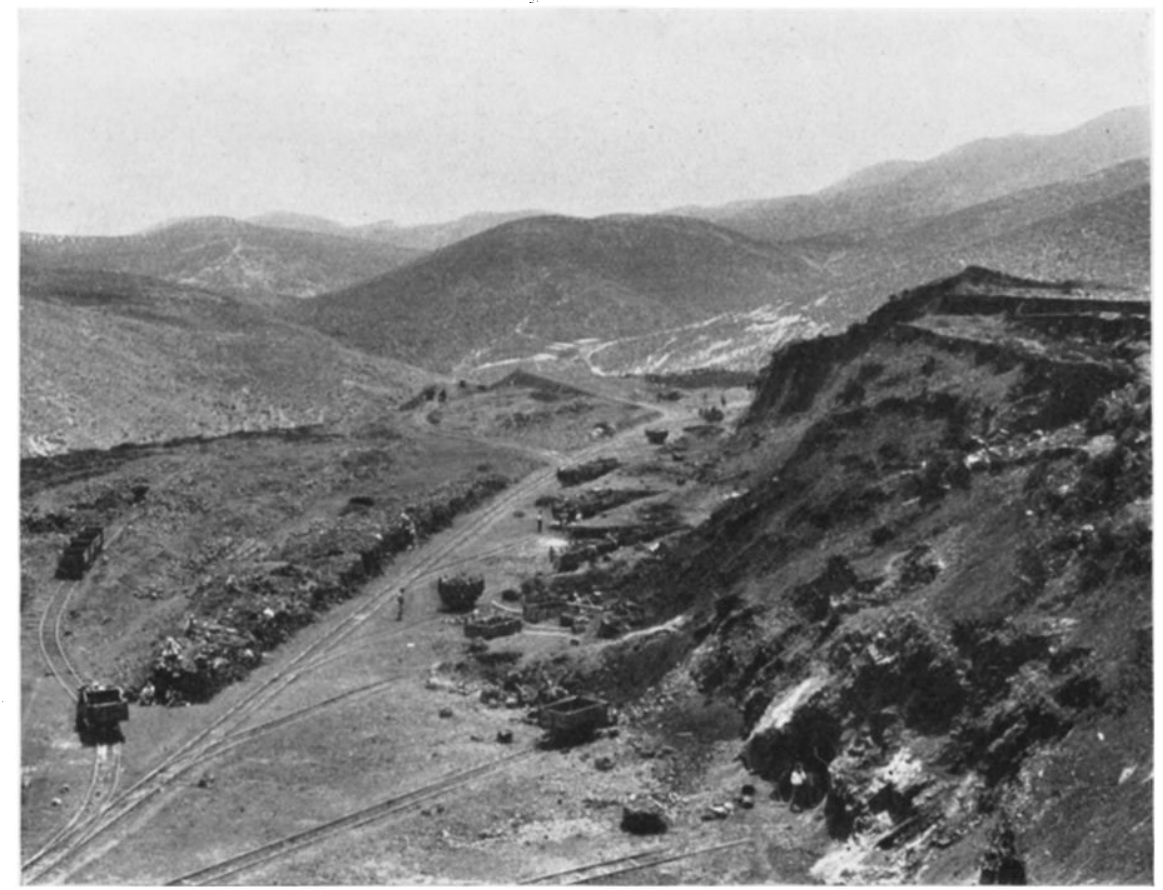

IRON-ORE MINE AT MOUNT UISHAN, SOUTH OF MELILLA 


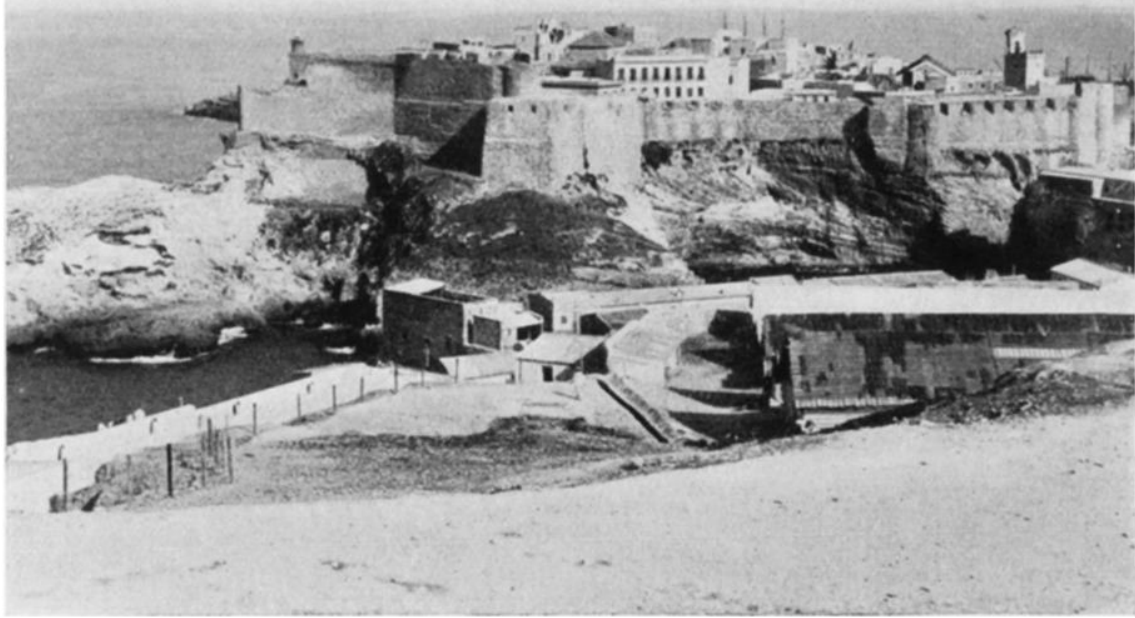

MELILLA IN IgOg

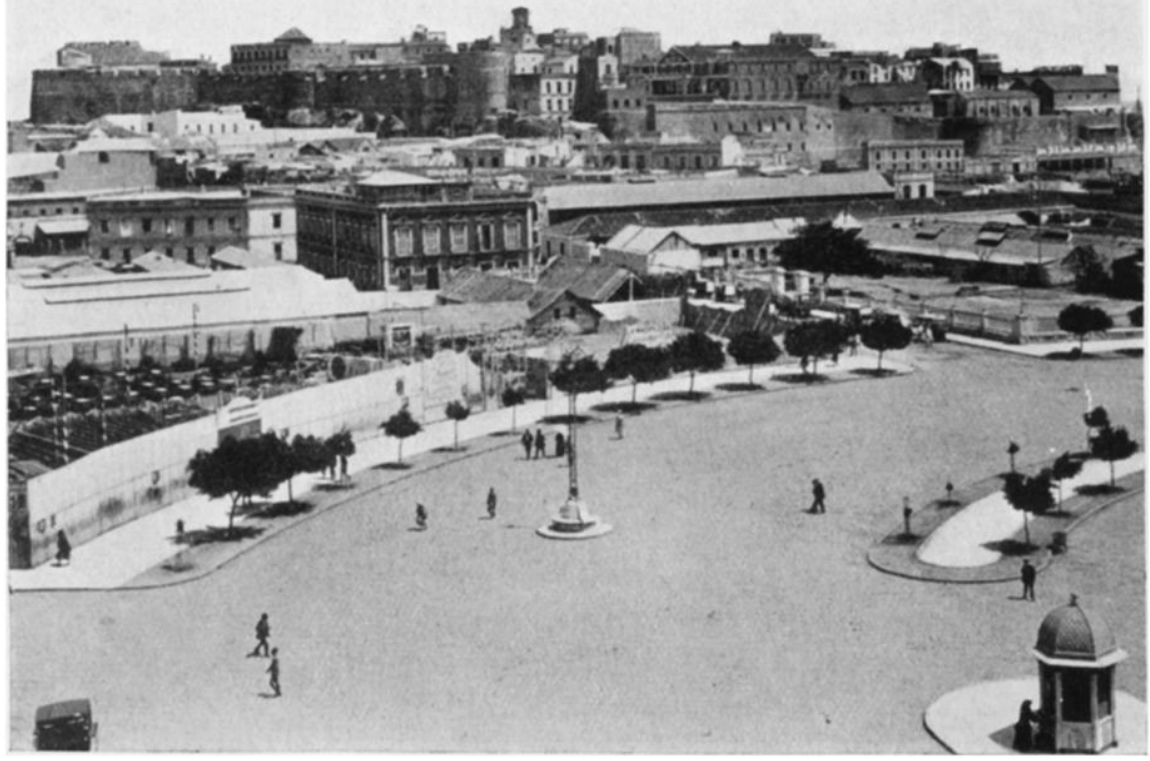

MELILLA IN IgI6 
agriculture is taught to the natives with improved machinery. Near Tetuan a horticultural station has been opened, where, among others, very successful experiments have been made with the cotton plant. The progress made, thanks to these measures, is shown by the fact that in the Melilla district the natives no longer eat barley but wheaten bread, while numerous prosperous Spanish villages and agricultural ventures, many of them in combination with the natives, are springing up. The land under cultivation has extended itself sevenfold in six years. Other plantations besides corn, such as vines, have been developed with success, while the Moors frequently take with them modern ploughs on loan into territory not yet submitted, without one case of theft having occurred up to the present. Forestry has also been introduced into both sections of the zone, particularly in the woods of the Laraiche and Arzila regions, the eucalyptus having been added to the native trees. Regulations have been framed for the preservation of trees and productive brushwood, the application of which is confided to the native police and foresters under European supervision. The veterinary stations and service established in the outlying districts are much appreciated by the Moors, and have proved one of the best means for peaceful penetration.

Of still greater value from this point of view are the hospitals and dispensaries for natives, the former in the larger towns, the latter in every village and military outpost. It is a common event for the Spanish military doctors to be called into the rebel country; men wounded by our troops are brought into our hospitals; and, greatest wonder of all, the women of the wildest tribes come to our physicians or the latter are invited to visit them in their homes. To the cure by Spanish doctors of Kaid Amar, chief of the M'talsa, is owing in great part the submission of this warlike people of the Rif, who dispose of 10,000 riflemen and 600 horsemen. Medical statistics show a considerable yearly increase in the number of cases treated.

As is well known, education is little more than nominal in Morocco. At $\mathrm{Fez}$ the so-called University of El Kairuan still subsists, but instruction in the towns and villages of the empire is reduced to little more than reading and writing and learning the Koran by heart. In the remoter districts of the Rif and Jebala even this rudimentary learning is unknown. On the other hand, Spain is confronted with the educational problem among her own nationals in Morocco, and has been obliged to cope with both on different lines. In order not to clash with religious sentiment she has not interfered with the existing schools, but has contented herself with having her language taught there, to the undisguised satisfaction of the Moors, keen as they are to acquire this additional means of developing their trade. Aided by clear-sighted Mohammedans she has set up in every large centre Spanish-Arabic schools, where higher teaching is imparted by capable Moorish :masters with Spanish co-operation and supervision. The Mohammedan University, or Medersa, has been 
restored at Tetuan to more than its pristine glory by enlisting the staff of thirteen professors among the best elements in our zone. The result of this policy has already been reaped. Native officials educated in these Islamic schools are now employed in the Post Office and other public services of the Protectorate.

Spanish children in Morocco have for generations past had their school in every coast town, even in far-off Mogador. Spain owes much in this and other respects to the Franciscan Order. For seven hundred years these humble patriots have worked among the local Christians and discreetly ministered to the temporal wants of Mussulmans and Jews, without hurting their religious susceptibilities. Thus, respected and honoured by all, they maintained the flickering flame of culture in halfforgotten corners of the world and kept the flag flying through the ages. On this foundation the Spanish State, whose colleges in Ceuta and Melilla do it credit, has established modern schools, open to all-comers without distinction of race or creed wherever Spaniards are to be found in Morocco.

The finest of these establishments are to be seen at Tangier, where the Alfonso XIII., the Playa, and San Francisco schools can accommodate over 2000 scholars of both sexes for primary and secondary instruction, including foreign languages and commercial courses. As you see, it is impossible to speak of the Spanish zone in Northern Morocco without mentioning Tangier as the geographical, ethnological, psychological, and therefore the logical part of a whole. Tangier is as thoroughly Spanish as any town beyond my nation's frontiers. Spanish is the language of high and low, European, Moor and Jew. The thought and sentiment, the life and sympathy, of the town are cast in Spanish moulds; Spanish are the names of her streets, Spanish the currency, Spanish the Press and theatre and the songs in the mouths of her children; even the young diplomat setting his foot for the first time on the quay discovers before passing through the gates that his highly prized smattering of Arabic is less useful than the tongue of that old African Cervantes. In fact, as a Britisher writing to a London paper last month expressed it: "One hardly knows whether one is in a Moorish city in Spain or a Spanish city in Morocco."

Gentlemen, I thank you for your hospitality! I thank you for so patiently bearing with me! You will not, I hope, think that I am trading on your longanimity if I sum up my words to-night by saying that I consider I have set hefore you a complete picture of the Spanish Protectorate in Morocco. That Spain's work there has been a success, a real and great success, is shown by the fact that, in spite of the extraordinary difficulty of coping with a people split up into small fractions, not ruled as in other parts of Morocco by great paramount chiefs, she has subdued and occupied 6300 square miles out of a total area of 10,800 square miles of hill country. Under her rule trade in Tetuan rose from $1,238,000$ pesetas in 1905 to $11,000,000$ pesetas in 1916 : at Melilla from 9,500,000 pesetas in 1905 to $59,578,000$ pesetas in 1916 ; at Ceuta from 572,000 pesetas in 
1905 to $15,800,000$ pesetas in 1915 , without counting goods entering and leaving for the Army.

British trade, moreover, represents 33 per cent. of the total commerce of Morocco (see Board of Trade $\mathcal{F}$ ournal of 27 January 1920). Tea, cotton goods, candles are the staple commodities in that country. All three are products of the British Empire or sold by British firms to the Moors; none of them clash with those imported by Spain. Melilla, Alhucemas, Velez de la Gomera, free ports every one, are the keys to the Rif. In the zone of the Spanish Protectorate British merchants, British enterprise of every kind and the British are welcome. Of that I can assure you, and I rejoice at this happy disposition so conducive to that close and profitable friendship between the two nations which is my heart's desire.

Note.-We recommend to the philologist the Grammar of Moorish Arabic and the Grammar of the Rif language published by the eminent Franciscan Lerelundi. Another scholar of his cloth, P. Pedro de Sarronandia, was cut off in his prime before publishing his comparative study of the Basque and Moorish-Berber tongues. An interesting article in Morocco of 4 October 1919 shows in greater detail the organization and results of Spanish education, very largely the work of Don Ricardo Ruiz, supplemented by another account in Morocco of II October I9I9

Before the paper the PRESIDENT said: At a meeting some time ago there was read before the Society a paper by Mr. MacLeod on the work of the French in Morocco. His Excellency the Spanish Ambassador notified to the Society that he would very much like to read us a paper upon the work of the Spanish in Morocco, and it is needless to say that we heartily welcomed His Excellency's kind offer. We are glad to welcome him because he is a Londoner; he was born in London and he was brought up in England, speaks English perfectly, and is thoroughly well acquainted with our customs. $\mathrm{He}$ has also served in Spanish Morocco as the representative of Spain, and is well acquainted with the subject about which he is to address us this evening. I have now the honour to ask His Excellency to give us his address.

\section{H.E. the Spanish Ambassador then read the paper printed above, and a discussion followed.}

The President: Sir Arthur Hardinge, until quite recently British Ambassador in Madrid, is present here this evening. He has a wide knowledge not only of Spain and of Morocco, but also very sympathetic and deep knowledge of oriental peoples, and I am sure any remarks he can make about the Spanish zone in Morocco and about its native inhabitants would be of special value to us.

Sir ARthur Hardinge : His Excellency the Spanish Ambassador is an old colleague, as we were together at Brussels; an old fellow-worker, since we have co-operated during the last seven years in the common task of maintaining the most cordial relations between our two countries-a task which the action of both our Governments have happily rendered an easy one-and in both these capacities he is an esteemed and valued friend. My knowledge of Morocco is slight and superficial when I compare it with that of my distinguished ex-colleague, who had the advantage of representing his country there during a long and I think a somewhat delicate period in the history of 